\begin{tabular}{|c|}
\hline 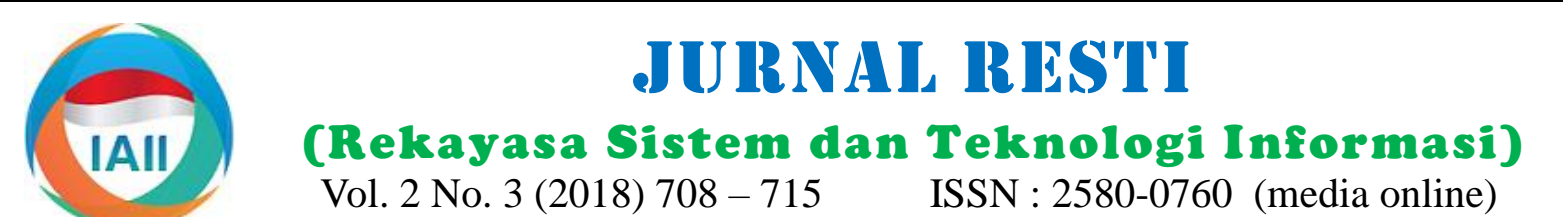 \\
\hline
\end{tabular}

\title{
Pengaruh Normalisasi Teks Dengan Text Expansion Dalam Deteksi Komentar Spam Pada Youtube
}

\author{
Imam Thoib $^{\mathrm{a}}$, Arief Setyanto ${ }^{\mathrm{b}}$, Suwanto Raharjo ${ }^{\mathrm{c}}$ \\ ${ }^{a}$ Magister Teknik Informatika, Universitas Amikom Yogyakarta, imam.thoib@students.amikom.ac.id \\ bMagister Teknik Informatika, Universitas Amikom Yogyakarta, arief_s@amikom.ac.id \\ cTeknik Informatika, Fakultas Teknologi Industri, Institut Sains \& Teknologi AKPRIND Yogyakarta,wa2n@akprind.ac.id
}

\begin{abstract}
The popularity of Youtube as the largest video sharing website in the wolrd give spammers opportunities to get benefit from Youtube in illegal ways by putting spam comments on Youtube's videos. Spam comments are very troubling to channel owners. The variants of spam comments are becoming more difficult to detect. One of them is spam comments using abbreviations, symbols, terms or misspelled word to make detection difficult. This research evaluate some classification techniques and employ text normalization method called TextExpansion to deal with this problem. This research uses Youtube Spam Collections dataset from UCI Machine Learning Library composed by five different datasets, which each one contains text comments extracted from YouTube videos (Psy, Katty Perry, LMFAO, Eminem and Shakira). The evaluation results shows TextExpansion is able to produce the highest accuracy value of $90.23 \%$. To determine the impact of applying the TextExpansion method, this research conducted $t$-test for each dataset. The results of t-test for each dataset shows $P(T<=t)$ two-tail $<0.05$ which indicates a significant impact after applying text normalization using TextExpansion.
\end{abstract}

Keywords: spam detection, text normalization, text expansion, youtube spam comments

\begin{abstract}
Abstrak
Popularitas Youtube sebagai website berbagi video terbesar di dunia memberikan celah kepada spammer untuk mendapatkan keuntungan dari Youtube dengan cara yang ilegal. Salah satu cara yang dilakukan adalah melakukan komentar spam pada video-video yang ada di Youtube. Komentar spam menjadi hal yang sangat meresahkan pemilik channel. Varian komentar spam kian banyak dan menyulitkan untuk dideteksi oleh Youtube. Peneliti melakukan evaluasi beberapa metode klasifikasi dengan menerapkan normalisasi teks pada tahap praproses menggunakan metode TextExpansion untuk mengatasi masalah ini. Dataset yang diuji adalah dataset Youtube Spam Collections dari UCI Machine Learning Library yang terdiri dari 5 dataset dari komentar yang diekstrak dari video Psy, Katy Perry, LMFAO, Eminem dan Shakira. Dataset terdiri dari 1005 komentar spam dan 951 komentar bukan spam. Hasil evaluasi menunjukkan TextExpansion mampu menghasilkan nilai akurasi tertinggi $90.23 \%$. Untuk mengetahui pengaruh penerapan metode TextExpansion, peneliti melakukan uji beda $t$-test pada setiap dataset. Hasil uji beda $t$-test pada setiap dataset menunjukkan nilai $P(T<=t)$ two-tail $<0.05$ yang menunjukkan adanya pengaruh yang signifikan setelah diterapkan normalisasi teks menggunkan metode TextExpansion.
\end{abstract}

Kata kunci: deteksi spam, normalisasi teks, text expansion, komentar spam youtube

(C) 2018 Jurnal RESTI

\section{Pendahuluan}

Saat ini Youtube menempati urutan pertama website berbagi video di dunia. Pada tahun 2018 ini, pengguna Youtube mencapai lebih dari 1 milyar atau mencapai $1 / 3$ dari seluruh pengguna Internet di dunia yang terdiri dari pengguna berusia 18-49 tahun[1]. Pada perkembangannya, lebih dari separuh penayangan di Youtube berasal dari perangkat mobile [1]. Hal ini menjadi sebuah pencapaian yang luar biasa bagi Google yang telah menyisihkan website berbagi video seperti Vimeo dan yang lainnya.
Namun, di balik pesatnya perkembangan dan banyaknya pengguna Youtube, terdapat tantangan yang dihadapi. Salah satunya adalah pemanfaatan Youtube yang tidak semestinya, yaitu spam. Salah satu jenis spam yang ada di Youtube adalah komentar spam. Ciri komentar spam di Youtube biasanya terdapat link ke situs pornografi, website online dating atau video yang tidak relevan yang biasanya dilakukan secara otomatis menggunakan mesin [2][3].

Spam bukanlah hal yang baru, sebuah perusahaan keamanan komputer bernama Nexgate merilis laporan

Diterima Redaksi : 18-10-2018 | Selesai Revisi : 30-10-2018 | Diterbitkan Online : 16-12-2018 
yang menunjukkan adanya peningkatan volume spam tersebut menunjukkan adanya peningkatan akurasi di media sosial sebesar 355\% di pertengahan tahun dalam deteksi SMS spam dibanding tanpa 2013. Facebook dan Youtube menempati peringkat menggunakan normalisasi teks. teratas, dimana ditemukan 100 komentar spam di Youtube dan Facebook setiap satu komentar spam ditemukan di sosial media lain[4].

Penggunaan teknik normalisasi teks juga dilakukan oleh beberapa peneliti untuk meningkatkan akurasi deteksi spam. Silva, R. M. et al. mengadopsi Banyaknya komentar spam di Youtube mengakibatkan TextExpansion untuk melakukan normalisasi teks pada beberapa channel mematikan fasilitas komentar pada deteksi komentar spam di Youtube menggunakan videonya. Seperti yang diberitakan oleh situs berita The metode MDLText. Penggunaan TextExpansion terbukti Guardian, pemilik channel PewDiePie yang telah meningkatkan nilai Spam Caught Rate (SC) pada memiliki 60 juta pengikut telah mematikan fasilitas deteksi komentar spam. Nilai SC yang diperoleh dari komentar pada videonya. PewDiePie menyatakan metode tersebut adalah 0.937[9].

bahwa mayoritas komentar di videonya adalah spam[5]. Jika tidak ditangani dengan serius, komentar spam dapat mengganggu pemilik channel dan pengguna Youtube lainnya.

Pada penelitian ini akan dilakukan normalisasi teks menggunakan TextExpansion[10] pada deteksi komentar spam di Youtube menggunakan metode klasifikasi Decision Tree, Logistic Regression, Nä̈ve Youtube sendiri sudah memiliki mekanisme untuk Bayes, K-Nearest Neighbour, Random Forest dan menangani komentar spam yaitu salah satunya dengan Support Vector Machine[6] untuk mengetahui memfasilitasi pengguna dengan tombol untuk pengaruh dari normalisasi teks pada deteksi komentar melaporkan sebuah komentar yang terindikasi spam. spam di Youtube.

Namun cara ini dinilai masih kurang maksimal karena bisa saja laporan dari pengguna merupakan laporan palsu. Banyaknya komentar juga menjadi masalah yang besar jika harus menghapus satu per satu komentar. Sehingga masalah ini menarik para peneliti untuk melakukan penelitian untuk menangani komentar spam secara otomatis.

Ada beberapa peneliti yang telah melakukan penelitian untuk menangani masalah spam ini dengan berbagai macam teknik dan metode. Penanganan komentar spam yang banyak dilakukan adalah menggunakan teknik machine learning dengan metode klasifikasi yang jamak digunakan seperti Support Vectore Machine email spam mengunan (SVM), Nä̈ve Bayes (NB) dan K-Nearest Longest Common Sequence (LCS) dikombinasikan Neighbour[6]. Metode-metode tersebut memberikan dengan metode Naïve Bayes[13], sedangkan Lee, C.-N. performa yang bagus untuk melakukan deteksi et al. menggunakan metode Weighted Naïve Bayes. komentar spam di Youtube[7].

Namun ada masalah yang dihadapi dalam penanganan komentar spam, di mana komentar spam tidak hanya dilakukan oleh mesin, melainkan juga dilakukan oleh pengguna asli[8]. Biasanya digunakan kalimat yang sangat pendek, singkatan, simbol, istilah dan ejaan Idris, I. et al. \& Zavvar, M. et al. melakukan optimasi yang salah untuk mempersulit pendeteksian komentar metode machine learning menggunakan Particle spam tersebut secara otomatis[9]. Hal ini tentunya Swarm Optimization (PSO). Negative Selection menarik untuk diteliti, diperlukan sebuah teknik Algorithm (NSA) dikombinasikan dengan PSO normalisasi teks pada proses pre-processing untuk menghasilkan nilai akurasi lebih rendah dibandingkan mengatasi masalah tersebut[9]. Diperlukan sebuah dengan metode SVM. Dimana NSA-PSO mendapatkan teknik normalisasi teks yang digunakan untuk nilai akurasi sebesar 83.2\% sedangkan SVM 90\%[11]. mengubah teks asli yang berisi singkatan dan simbol Sebaliknya performa SVM-PSO menunjukkan akurasi menjadi teks yang standar[10]. terbaik untuk mendeteksi email spam[14].

Almeida, T. A. et al. merancang TextExpansion untuk Pada era media sosial saat ini telah dilakukan penelitian melakukan normalisasi teks pada penanganan SMS untuk mendeteksi spam di media sosial [15][16][17]. spam. Teknik nomalisasi tersebut memanfaatkan Salah satu contohnnya adalah pendeteksian komentar Freeling English dan NoSlang Dictionary untuk spam pada Twitter menggunakan teknik machine mengkonversi teks asli menjadi teks yang standar dan learning. Metode Hidden Markov Model (HMM) tanpa singkatan[6]. Penggunaan TextExpansion

Jurnal RESTI (Rekayasa Sistem dan Teknologi Informasi) Vol. 2 No. 3 (2018) 708 - 715 
menunjukkan hasil akurasi yang baik dalam deteksi komentar spam di Twitter[15].

Deteksi komentar spam menghadapi masalah dimana spam dilakukan tidak hanya oleh mesin[8], melainkan juga dilakukan oleh pengguna asli. Mereka menggunakan simbol, singkatan, istilah dan menggunakan kata yang sengaja disalahkan ejaannya untuk mempersulit penyaringan. Diperlukan sebuah teknik untuk mengubah teks tersebut menjadi teks yang tersebut disebut teknik normalisasi teks. Pada penelitian ini akan ditambahkan proses normalisasi teks yang diadopsi dari metode TextExpansion untuk mengatasi masalah ini[10].

\section{Metodologi Penelitian}

Langkah-langkah yang dilakukan dalam penelitian disajikan dalam alur penelitian pada gambar 1 .

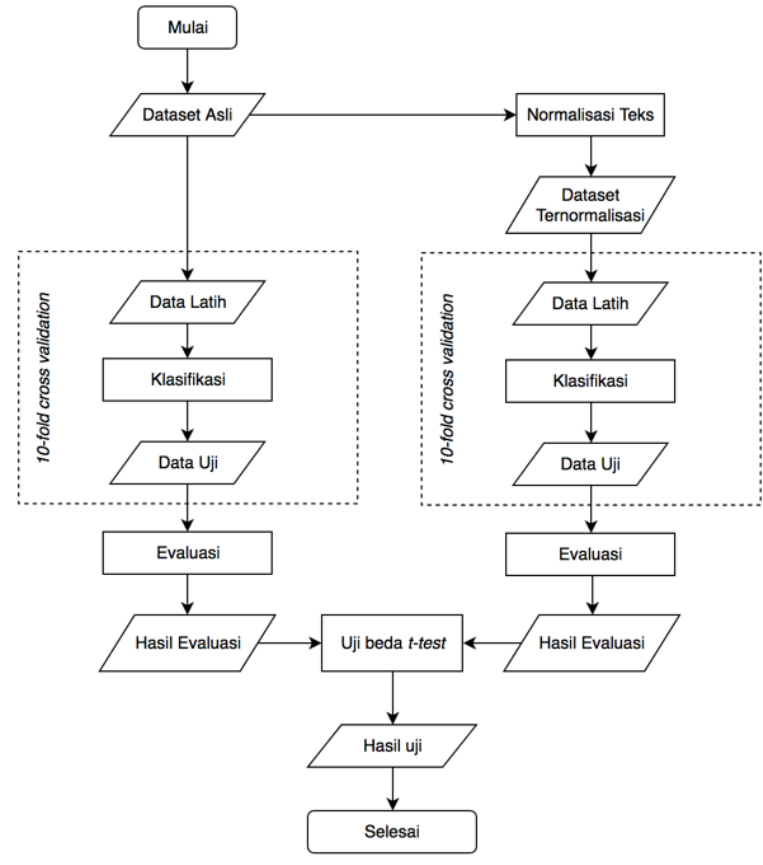

Gambar 1. Alur Penelitian standar, sehingga mempermudah filterisasi. Teknik

Tabel 1. Proporsi komentar spam dan ham

\begin{tabular}{llll}
\hline Dataset & Spam & Ham & Total \\
\hline Psy & 175 & 175 & 350 \\
KattyPerry & 175 & 175 & 350 \\
LMFAO & 236 & 202 & 436 \\
Eminem & 245 & 203 & 448 \\
Shakira & 174 & 196 & 370 \\
\hline Total & 1005 & 951 & 1956 \\
\hline \multicolumn{4}{l}{} \\
& Tabel 2. Contoh komentar spam dan ham \\
\hline Jenis & Komentar \\
\hline \multirow{2}{*}{ Spam } & Hey, check out my new website!! This site is about \\
& kids stuff. Kidsmediausa . com \\
Ham & This video will get to 2 billion just because of \\
& people checking if it has hit 2 billion yet. \\
\hline
\end{tabular}

Setiap dataset ini akan digunakan pada proses normalisasi teks dan klasifikasi, kemudian dibandingkan hasil pengujiannya antara dataset yang dinormalisasi dan yang tidak.

\subsection{Metode Normalisasi Teks}

Pada tahap ini dilakukan normalisasi teks pada setiap dataset untuk mengubah teks asli menjadi teks ternormalisasi. Metode yang digunakan adalah TextExpansion. Pada tahap ini akan diterapkan semua aturan yang ada pada metode TextExpansion. Terdapat 10 aturan pada metode TextExpansion yang disajikan pada tabel 3 .

Tabel 3. Aturan TextExpansion

\begin{tabular}{|c|c|}
\hline Aturan & Keterangan \\
\hline Expansion 1 & Concept Generations \\
\hline Expansion 2 & Word Sense Disambiguation \\
\hline Expansion 3 & Text Normalization \\
\hline Expansion 4 & $\begin{array}{l}\text { Text Normalization + Concept } \\
\text { Generations }\end{array}$ \\
\hline Expansion 5 & $\begin{array}{l}\text { Text Normalization + Word Sense } \\
\text { Disambiguation }\end{array}$ \\
\hline Expansion 6 & Original Text + Concept Generations \\
\hline Expansion 7 & $\begin{array}{l}\text { Original Text }+ \text { Word Sense } \\
\text { Disambiguation }\end{array}$ \\
\hline Expansion 8 & Original Text + Text Normalization \\
\hline Expansion 9 & $\begin{array}{l}\text { Original Text }+ \text { Text Normalization }+ \\
\text { Concept Generations }\end{array}$ \\
\hline Expansion 10 & $\begin{array}{l}\text { Original Text }+ \text { Text Normalization }+ \\
\text { Word Sense Disambiguation }\end{array}$ \\
\hline
\end{tabular}

Pada tahap ini digunakan sebuah library bernama TextExpansion Tool pada python 2.76 untuk melakukan

\subsection{Dataset}

Untuk mendapatkan hasil yang akurat, peneliti proses normalisasi teks. Setiap dataset akan menggunakan dataset yang terpercaya sebagai bahan menghasilkan 10 dataset ekspansi hasil normalisasi penelitian. Dataset yang digunakan adalah dataset teks. Total dataset yang akan diuji sebanyak 55 dataset Youtube Spam Collections dari UCI Machine Learning termasuk dataset asli. Dataset ekspansi akan diberi Library yang terdiri dari 5 dataset dari komentar yang nama sesuai dengan aturan yang diterapkan pada tabel diekstrak dari video Psy, Katy Perry, LMFAO, Eminem 3.

and Shakira[6]. Pada setiap dataset terdapat komentar spam dan ham dengan jumlah yang berbeda. Rincian jumlah komentar spam dan ham pada setiap dataset dapat dilihat pada tabel 1.

\subsection{Metode Klasifikasi}

Pada tahap ini dilakukan klasifikasi pada setiap dataset, baik dataset asli maupun dataset hasil normalisasi. Metode klasifikasi yang akan digunakan dapat dilihat pada tabel 4.

Salah satu contoh komentar spam dan ham yang terdapat pada dataset yang akan diuji dapat dilihat pada tabel 2 . 
Tabel 4. Metode klasifikasi

\begin{tabular}{ll}
\hline Metode & Keterangan \\
\hline DT & Decision Trees \\
LR & Logistic Regression \\
NB-B & Bernoulli Nä̈ve Bayes \\
NB-G & Gaussian Nä̈ve Bayes \\
NB-M & Mulninomial Nä̈ve Bayes \\
1-NN & 1-Nearest Neighbour \\
3-NN & 3-Nearest Neighbours \\
5-NN & 5-Nearest Neighbours \\
RF & Random Forests \\
SVM-L & Support Vector Machine dengan kernel linier \\
SVM-P & Support Vector Machine dengan kernel \\
SVM-R & polynomial \\
\hline
\end{tabular}

Parameter metode klasifikasi yang digunakan pada setiap dataset berbeda. Digunakan parameter yang sama dengan peneliti sebelumnya yang dapat dilihat pada tabel 5.

Tabel 5. Parameter metode klasifikasi

\begin{tabular}{|c|c|c|c|c|c|c|}
\hline \multirow[b]{2}{*}{ Metode } & \multirow[b]{2}{*}{ Parameter } & \multicolumn{5}{|c|}{ Dataset } \\
\hline & & Psy & $\begin{array}{l}\text { Katty } \\
\text { Perry }\end{array}$ & LMFAO & $\begin{array}{l}\text { Emi } \\
\text { nem }\end{array}$ & $\begin{array}{l}\text { Sha } \\
\text { kira }\end{array}$ \\
\hline LR & $\bar{C}$ & 10 & $10^{5}$ & $10^{2}$ & $10^{2}$ & $10^{2}$ \\
\hline NB-B & $\alpha$ & 1 & 10 & $10^{-2}$ & $10^{-3}$ & $10^{-5}$ \\
\hline NB-M & $\alpha$ & 1 & 10 & $10^{-5}$ & $10^{-1}$ & $10^{-2}$ \\
\hline $\mathrm{RF}$ & \#trees & 80 & 40 & 90 & 30 & 30 \\
\hline $\begin{array}{c}\text { SVM- } \\
\text { L }\end{array}$ & C & $\begin{array}{c}10^{-} \\
1\end{array}$ & $10^{-1}$ & 1 & $10^{-1}$ & 1 \\
\hline SVM- & C & $\begin{array}{c}10^{-} \\
5\end{array}$ & $10^{-4}$ & $10^{-3}$ & $10^{-5}$ & $10^{-4}$ \\
\hline $\mathrm{P}$ & $r$ & 10 & 10 & 10 & $10^{2}$ & 10 \\
\hline & $C$ & 1 & $10^{3}$ & $10^{3}$ & $10^{3}$ & $10^{2}$ \\
\hline $\mathrm{R}$ & $r$ & $\begin{array}{c}10^{-} \\
2\end{array}$ & $10^{-2}$ & $10^{-3}$ & $10^{-4}$ & $10^{-2}$ \\
\hline
\end{tabular}

Selain yang disajikan pada tabel 5, digunakan parameter bawaan dari metode yang digunakan. Library yang digunakan untuk proses klasifikasi adalah scikit-learn v.0.16.1 pada python 2.7.6[6].

\subsection{Metode Evaluasi}

Pada tahap ini akan dilakukan evaluasi terhadap hasil klasifikasi. Metode $k$-fold cross validation digunakan untuk melipat data dan mengulangi eksperimen sebanyak $k$. Pada penelitian ini akan digunakan 10-fold cross validation, dimana ekseperimen akan dilakukan sebanyak 10 kali dengan proporsi data latih dibanding data uji 9:1.

Selanjutnya, untuk membandingkan performa dari setiap metode klasifikasi, digunakan beberapa metode pengukuran yaitu: akurasi (Acc), Spam Caught Rate (SC), Blocked Ham Rate (BH), F-measure (F1), Matthews Correlation Coefficient (MCC). Hasil evaluasi akan disajikan dalam bentuk tabel yang akan menampilkan nilai pengukuran klasifikasi pada setiap dataset.

\subsection{Uji Beda $t$-test}

Untuk mengetahui pengaruh dari metode TextExpansion pada deteksi komentar spam dilakukan uji beda t-test. Dengan uji beda t-test nantinya akan dapat diketahui signifikan atau tidaknya pengaruh dari penerapan metode TextExpansion. Nilai $\alpha$ yang digunakan adalah 0.05 dengan tingkat kepercayaan 95\%. Apabila nilai $P(T<=t)$ two-tail $<\alpha$ maka pengaruh penerapan metode TextExpansion adalah signifikan, sebaliknya jika nilai $P(T<=t)$ two-tail $>\alpha$ maka penerapan metode TextExpansion dikatakan tidak signifikan.

\section{Hasil dan Pembahasan}

\subsection{Hasil Normalisasi Teks}

Pada proses ini dilakukan normalisasi teks untuk mengubah teks asli menjadi teks ternormalisasi. Metode yang digunakan pada proses ini adalah metode TextExpansion. Proses normalisasi teks pada masingmasing dataset membutuhkan waktu yang bervariasi. Peneliti mencatat waktu yang digunakan untuk normalisasi teks setiap dataset pada tabel 6 .

Tabel 6. Waktu Normalisasi Teks

\begin{tabular}{lllll}
\hline \multirow{2}{*}{ Dataset } & $\begin{array}{l}\text { Total } \\
\text { Data }\end{array}$ & \multicolumn{3}{l}{ Waktu (menit) } \\
\cline { 3 - 5 } & 350 & 163 & 964 & 24 \\
\hline Psy & 350 & 162 & 205 & 23 \\
Katty Perry & 350 & User & Sistem \\
LMFAO & 438 & 136 & 189 & 22 \\
Eminem & 453 & 208 & 271 & 30 \\
Shakira & 370 & 170 & 219 & 24 \\
\hline
\end{tabular}

Proses normalisasi teks tercepat diperoleh dari dataset LMFAO yaitu selama 136 menit, sedangkan dataset Eminem membutuhkan waktu paling lama pada proses ini yaitu selama 208 menit.

Dari proses normalisasi teks ini dihasilkan 10 variasi dataset yang disebut dataset expansion yang menerapkan aturan pada tabel 3. Hal ini mengakibatkan waktu komputasi yang dibutuhakan pada tahap ini relatif lama. Hasil dari proses normalisasi teks dapat dilihat pada gambar 2 .

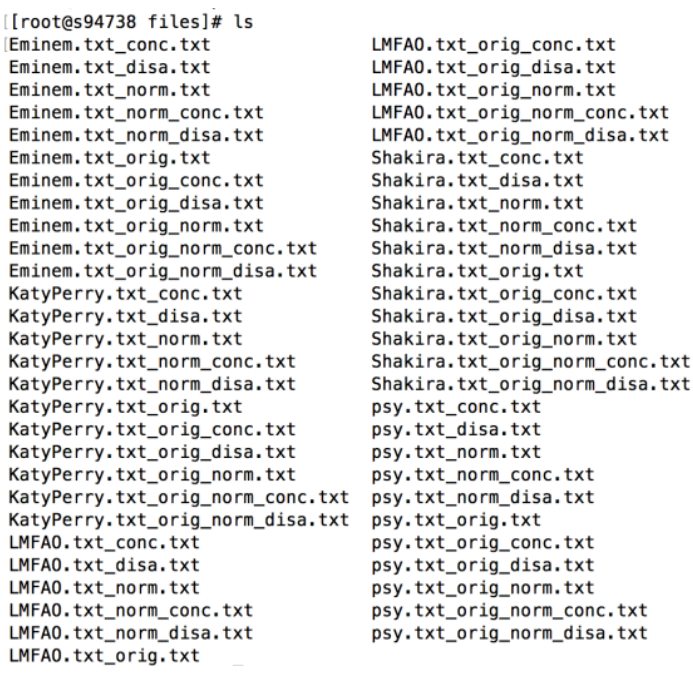

Gambar 2. Output Hasil Normalisasi Teks 
Hasil normalisasi teks disimpan dalam file berekstensi Regression. Hal ini menunjukkan performa yang bagus .txt. Bubuhan pada setiap file menandakan hasil dari dihasilkan dari metode Logistic Regression. rule yang digunakan. Contoh hasil dari normalisasi teks dapat dilihat pada tabel 7 .

\section{Tabel 7. Hasil Normalisasi Teks}

\begin{tabular}{|c|c|}
\hline Original & +447935454150 lovely girl talk to me xxxï»i \\
\hline Expansion 1 & $\begin{array}{l}+447935454150 \text { lovely pin-up female_child fille } \\
\text { girl girlfriend lady_friend little_girl miss missy } \\
\text { young_lady young_woman public_lecture talk } \\
\text { talk_of_the_town talking to me xxxï»i }\end{array}$ \\
\hline Expansion 2 & $\begin{array}{l}+44 \overline{7} 935454150 \text { adorable female_child talk to } \\
\text { me xxxï»i. }\end{array}$ \\
\hline Expansion 3 & $\begin{array}{l}+447935454150 \text { lovely girl talk to me xxxï»i } \\
+447935454150 \text { lovely lovely pin-up girl }\end{array}$ \\
\hline Expansion 4 & $\begin{array}{l}\text { female_child fille girl girlfriend lady_friend } \\
\text { little_girl miss missy young_lady young_woman } \\
\text { talk public_lecture talk talk_of_the_town talking } \\
\text { to me xxxï»i}\end{array}$ \\
\hline Expansion 5 & $\begin{array}{l}+447935454150 \text { lovely adorable girl } \\
\text { female_child talk to me xxxï»i } \\
+447935454150 \text { lovely lovely pin-up girl } \\
\text { female_child fille girl girlfriend lady_friend }\end{array}$ \\
\hline Expansion 6 & $\begin{array}{l}\text { little_girl miss missy young_lady young_woman } \\
\text { talk public_lecture talk talk_of_the_town talking } \\
\text { to me xxxï» } i\end{array}$ \\
\hline Expansion 7 & $\begin{array}{l}+447935454150 \text { lovely adorable girl } \\
\text { female_child talk to me xxxï»i }\end{array}$ \\
\hline Expansion 8 & $\begin{array}{l}+447935454150 \text { lovely girl talk to me xxxï»i } \\
+447935454150 \text { lovely lovely pin-up girl } \\
\text { female_child fille girl girlfriend lady_friend }\end{array}$ \\
\hline Expansion 9 & $\begin{array}{l}\text { little_girl miss missy young_lady young_woman } \\
\text { talk public_lecture talk talk_of_the_town talking } \\
\text { to me xxxï» } i\end{array}$ \\
\hline $\begin{array}{l}\text { Expansion } \\
10\end{array}$ & $\begin{array}{l}+447935454150 \text { lovely adorable girl } \\
\text { female_child talk to me xxxï»i }\end{array}$ \\
\hline
\end{tabular}

\subsection{Hasil Klasifikasi}

Pada proses ini dilakukan klasifikasi terhadap 55 dataset yang terdiri dari dataset original dan dataset expansion. Pada proses klasifikasi ini dataset dibagi menjadi data latih dan data uji yang dibagi secara otomatis menggunakan metode $k$-Fold Cross Validation. Pada penelitian ini digunakan $\mathrm{k}=10$. Pada proses klasifikasi ini akan diperoleh nilai Accuracy (Acc), Spam Caught Rate (SC), Blocked Ham Rate (BH), F-Measure (F1) dan Matthews Correlation Coefficient (MCC). Pada tabel 8-12 disajikan hasil pengukuran nilai MCC pada setiap dataset, yang mana nilai MCC akan menjadi tolak ukur untuk mengetahui kualitas klasifikasi binary.

Nilai MCC yang ditampilkan adalah nilai MCC yang diperoleh dari dataset original dan dataset expansion dengan nilai MCC terbaik. Nilai MCC yang dihasilkan berkisar antara -1 s.d. 1 . Nilai 1 menunjukkan nilai prediksi yang sempurna, 0 menunjukkan kegagalan dalam prediksi dan nilai -1 menunjukkan kegagalan total dalam prediksi [18].

Pada tabel 8 dapat diketahui nilai MCC yang diperoleh dari dataset Psy. Nilai MCC tertinggi sebesar 0.949 pada dataset expansion diperoleh dari metode Logistic
Tabel 8. Nilai MCC pada Dataset Psy

\begin{tabular}{ccc}
\hline Metode & Original & Expansion \\
\hline DT & 0.846 & 0.863 \\
LR & 0.932 & $\mathbf{0 . 9 4 9}$ \\
NB-B & 0.9 & 0.912 \\
NB-G & 0.669 & 0.697 \\
NB-M & 0.903 & 0.899 \\
1-NN & 0.458 & 0.823 \\
3-NN & 0.754 & 0.909 \\
5-NN & 0.824 & 0.937 \\
RF & 0.91 & 0.934 \\
SVM-L & 0.91 & 0.928 \\
SVM-P & 0.359 & 0.585 \\
SVM-R & 0.865 & 0.892 \\
\hline
\end{tabular}

Tabel 9. Nilai MCC pada Dataset KattyPerry

\begin{tabular}{ccc}
\hline Metode & Original & Expansion \\
\hline DT & 0.876 & 0.87 \\
LR & 0.909 & 0.898 \\
NB-B & 0.469 & 0.544 \\
NB-G & 0.655 & 0.682 \\
NB-M & 0.837 & 0.877 \\
1-NN & 0.404 & 0.744 \\
3-NN & 0.705 & 0.825 \\
5-NN & 0.741 & 0.841 \\
RF & 0.9 & 0.895 \\
SVM-L & 0.838 & 0.861 \\
SVM-P & 0.226 & 0.514 \\
SVM-R & 0.886 & $\mathbf{0 . 9 1 4}$ \\
\hline
\end{tabular}

Pada tabel 9 diperoleh nilai MCC tertinggi 0.914 pada dataset dari dataset KattyPerry. Nilai tersebut diperoleh dari dataset expansion menggunakan metode SVM dengan kernel gaussian.

Tabel 10. Nilai MCC pada Dataset LMFAO

\begin{tabular}{ccc}
\hline Metode & Original & Expansion \\
\hline DT & 0.881 & 0.891 \\
LR & 0.89 & $\mathbf{0 . 9 0 9}$ \\
NB-B & 0.881 & 0.904 \\
NB-G & 0.779 & 0.789 \\
NB-M & 0.723 & 0.812 \\
1-NN & 0.644 & 0.769 \\
3-NN & 0.71 & 0.803 \\
5-NN & 0.748 & 0.85 \\
RF & 0.887 & 0.903 \\
SVM-L & 0.876 & 0.905 \\
SVM-P & 0.693 & 0.734 \\
SVM-R & 0.871 & 0.904 \\
\hline
\end{tabular}

Pada tabel 10 dihasilkan nilai MCC pada dataset LMFAO. Performa metode klasifikasi terbaik dengan nilai MCC 0.909 diperoleh dari dataset expansion dengan metode Logistic Regression.

Pada tabel 11 diketahui nilai MCC tertinggi pada dataset Eminem sebesar 0.932. Nilai tersebut diperoleh dari dataset expansion menggunakan metode klasifikasi SVM dengan kernel gaussian. 
Imam Thoib, Arief Setyanto, Suwanto Raharjo

Jurnal RESTI (Rekayasa Sistem dan Teknologi Informasi) Vol . 2 No. 3 (2018) 708 - 715

Tabel 11. Nilai MCC pada Dataset Eminem

\begin{tabular}{ccc}
\hline Metode & Original & Expansion \\
\hline DT & 0.876 & 0.915 \\
LR & 0.892 & 0.928 \\
NB-B & 0.847 & 0.878 \\
NB-G & 0.726 & 0.776 \\
NB-M & 0.76 & 0.854 \\
1-NN & 0.487 & 0.767 \\
3-NN & 0.406 & 0.799 \\
5-NN & 0.426 & 0.83 \\
RF & 0.866 & 0.929 \\
SVM-L & 0.851 & 0.906 \\
SVM-P & 0.77 & 0.847 \\
SVM-R & 0.849 & $\mathbf{0 . 9 3 2}$ \\
\hline
\end{tabular}

Tabel 12. Nilai MCC pada Dataset Shakira

\begin{tabular}{ccc}
\hline Metode & Original & Expansion \\
\hline DT & 0.797 & 0.851 \\
LR & 0.875 & $\mathbf{0 . 9 0 3}$ \\
NB-B & 0.837 & 0.826 \\
NB-G & 0.741 & 0.75 \\
NB-M & 0.835 & 0.844 \\
1-NN & 0.564 & 0.594 \\
3-NN & 0.462 & 0.525 \\
5-NN & 0.7 & 0.747 \\
RF & 0.851 & 0.889 \\
SVM-L & 0.881 & 0.893 \\
SVM-P & 0.793 & 0.827 \\
SVM-R & 0.875 & $\mathbf{0 . 9 0 3}$ \\
\hline
\end{tabular}

Pada tabel 12 diperoleh nilai MCC pada dataset Shakira. Nilai MCC tertinggi sebesar 0.903 diperoleh dari dataset expansion menggunakan metode SVM-R.

Dari keseluruhan pengukuran nilai MCC pada setiap dataset, dapat diketahui 2 metode yang menghasilkan nilai MCC tertinggi dengan dataset expansion yaitu metode SVM dengan kernel gaussian dan Logistic Regression.

\subsection{Hasil Uji Beda t-test}

Pada tahap ini dilakukan uji beda t-test pada nilai MCC yang diperoleh untuk mengetahui adanya pengaruh yang signifikan atau tidak setelah diterapkan metode TextExpansion. Hasil uji beda $t$-test pada setiap dataset disajikan pada tabel 13-17.

Tabel 13. Uji Beda t-test pada Dataset Psy

\begin{tabular}{lrr}
\hline & Original & Expansion \\
\hline Mean & 0.7775 & 0.860666667 \\
Variance & 0.035799727 & 0.012287879 \\
Observations & 12 & 12 \\
Pearson Correlation & 0.840262467 & \\
Hypothesized Mean & & \\
Difference & 0 & \\
df & 11 & \\
t Stat & -2.542428185 & \\
P $(T<=$ t) one-tail & 0.013680728 & \\
t Critical one-tail & 1.795884819 & \\
P $(T<=t)$ two-tail & 0.027361456 & \\
t Critical two-tail & 2.20098516 & \\
\hline
\end{tabular}

Tabel 14. Uji Beda t-test pada Dataset KattyPerry

\begin{tabular}{lrr}
\hline & Original & Expansion \\
\hline Mean & 0.703833333 & 0.78875 \\
Variance & 0.050570333 & 0.019214023 \\
Observations & 12 & 12 \\
Pearson Correlation & 0.906664335 & \\
Hypothesized Mean & & \\
Difference & 0 & \\
df & 11 & \\
t Stat & -2.554509116 & \\
P $(\mathrm{T}<=$ t) one-tail & 0.013389603 & \\
t Critical one-tail & 1.795884819 & \\
P $(\mathrm{T}<=$ t) two-tail & 0.026779206 & \\
t Critical two-tail & 2.20098516 & \\
\hline
\end{tabular}

Tabel 15. Uji Beda t-test pada Dataset LMFAO

\begin{tabular}{lrr}
\hline & Original & Expansion \\
\hline Mean & 0.798583333 & 0.84775 \\
Variance & 0.008412992 & 0.004014386 \\
Observations & 12 & 12 \\
Pearson Correlation & 0.924142784 & \\
Hypothesized Mean & & \\
Difference & 0 & \\
df & 11 & \\
t Stat & -4.147754948 & \\
P(T<=t) one-tail & 0.000811302 & \\
t Critical one-tail & 1.795884819 & \\
P(T<=t) two-tail & 0.001622604 & \\
t Critical two-tail & 2.20098516 & \\
\hline
\end{tabular}

Tabel 16. Uji Beda t-test pada Dataset Eminem

\begin{tabular}{|c|c|c|}
\hline & Original & Expansion \\
\hline Mean & 0.729666667 & 0.863416667 \\
\hline Variance & 0.033409333 & 0.003674992 \\
\hline Observations & 12 & 12 \\
\hline Pearson Correlation & 0.78600043 & \\
\hline \multicolumn{3}{|l|}{ Hypothesized Mean } \\
\hline Difference & 0 & \\
\hline df & 11 & \\
\hline t Stat & -3.303924851 & \\
\hline $\mathrm{P}(\mathrm{T}<=\mathrm{t})$ one-tail & 0.003514436 & \\
\hline t Critical one-tail & 1.795884819 & \\
\hline $\mathrm{P}(\mathrm{T}<=\mathrm{t})$ two-tail & 0.007028871 & \\
\hline t Critical two-tail & 2.20098516 & \\
\hline \multicolumn{3}{|c|}{ Tabel 17. Uji Beda t-test pada Dataset Shakira } \\
\hline & Original & Expansion \\
\hline Mean & 0.767583333 & 0.796 \\
\hline Variance & 0.017624992 & 0.015173455 \\
\hline Observations & 12 & 12 \\
\hline Pearson Correlation & 0.989188546 & \\
\hline \multicolumn{3}{|l|}{ Hypothesized Mean } \\
\hline Difference & 0 & \\
\hline df & 11 & \\
\hline t Stat & -4.664553436 & \\
\hline $\mathrm{P}(\mathrm{T}<=\mathrm{t})$ one-tail & 0.000344302 & \\
\hline t Critical one-tail & 1.795884819 & \\
\hline $\mathrm{P}(\mathrm{T}<=\mathrm{t})$ two-tail & 0.000688604 & \\
\hline t Critical two-tail & 2.20098516 & \\
\hline
\end{tabular}

Dari keseluruhan hasil uji beda t-test pada setiap dataset diperoleh nilai $P(T<=t)$ two-tail $<0.05$. Hal ini menunjukkan bahwa adanya pengaruh yang signifikan setelah diterapkan normalisasi teks menggunakan metode TextExpansion. Untuk mengetahui aturan expansion terbaik, disajikan grafik perbandingan akurasi dari setiap dataset expansion pada gambar 3 . 


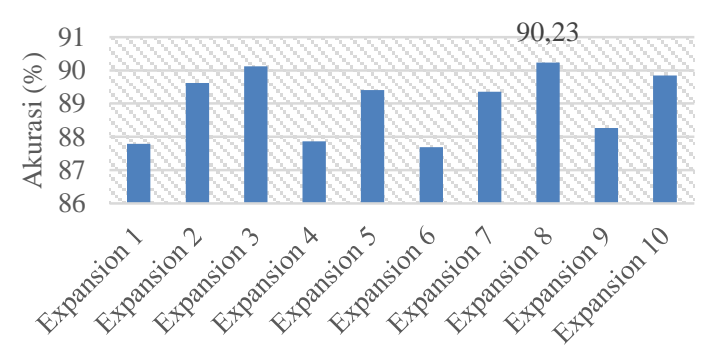

Gambar 3. Perbandingan Akurasi Dataset Expansion

Dari gambar 3 dapat diketahui nilai akurasi tertinggi 90.23\% diperoleh dari dataset Expansion 8. Dimana merupakan representasi dari aturan Original Text + Text Normalization + Concept Generations. Sehingga dapat disimpulkan aturan Expansion 8 adalah aturan terbaik pada kasus ini.

Selanjutnya untuk mengetahui metode klasifikasi dengan akurasi terbaik dilakukan penghitungan nilai gap akurasi dari dataset asli dan dataset expansion. Nilai gap akurasi dapat dilihat pada gambar 4 .

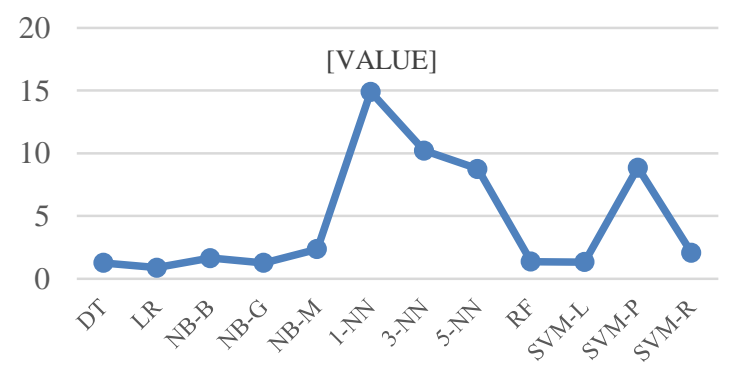

Gambar 4. Grafik gap akurasi

Dari grafik pada gambar 4 dapat diketahui metode KNN dengan $k=1$ menunjukkan nilai gap tertinggi sebesar 14.89. Hal ini menunjukkan adanya peningkatan akurasi yang signifikan setelah diterapkan metode TextExpansion, dimana nilai akurasi dataset asli sebesar $71.68 \%$ dan dataset expansion sebesar $86.58 \%$.

\section{Kesimpulan}

\subsection{Simpulan}

Berdasarkan hasil penelitian dan serangkaian uji coba yang dilakukan dapat disimpulkan bahwa penerapan normalisasi teks menggunakan metode TextExpansion untuk deteksi komentar spam pada Youtube menunjukkan hasil yang baik. Keseluruhan hasil uji beda t-test menunjukkan adanya pengaruh yang signifikan setelah diterapkan metode TextExpansion. Hal ini ditunjukkan dengan nilai nilai $P(T<=t)$ two-tail $<0.05$ pada seluruh dataset. Nilai akurasi tertinggi yang dihasilkan adalah $90.23 \%$ diperoleh dari dataset Expansion 8, dimana aturan tersebut merupakan kombinasi dari original text + text normalization $+[8]$ concept generations. Dari sini dapat disimpulkan bahwa aturan Expansion 8 merupakan aturan terbaik untuk deteksi komentar spam pada Youtube. Sedangkan jika ditinjau dari nilai MCC, metode SMV$\mathrm{R}$ dan Logistic Regression menunjukkan kualitas klasifikasi terbaik. Selanjutnya jika ditinjau dari gap akurasi, metode $\mathrm{K}-\mathrm{NN}$ dengan $k=1$ menunjukkan adanya peningkatan yang pesat sebesar $14.89 \%$ setelah menerapkan metode TextExpansion.

Dari hasil penelitian ini diharapkan dapat menjadi acuan untuk pengembangan tool untuk mendeteksi komentar spam secara otomatis pada Youtube yang lebih baik. Pada penelitian ini belum fokus pada satu metode klasifikasi, pada penelitian selanjutnya dapat dilakukan penelitian yang lebih mendalam pada metode klasifikasi terbaik dikombinasikan dengan metode TextExpansion untuk mendapatkan hasil yang lebih baik.

\subsection{Saran}

Pada penelitian ini tentunya masih banyak kekurangan, maka dari itu peneliti merangkum saran-saran untuk penelitian selanjutnya sebagai berikut:

1. Optimasi tool untuk TextExpansion karena masih dibutuhkan waktu yang lama dalam proses TextExpansion

2. Optimasi paramater pada setiap dataset Expansion menggunakan grid search untuk mendapatkan parameter terbaik pada setiap dataset

3. Mencari metode yang tepat untuk memilih dataset Expansion terbaik

\section{Daftar Rujukan}

[1] Youtube, "Press - Youtube," 2018. [Online]. Available: https://www.youtube.com/yt/about/ press/\%0D. [Accessed: 02-Mar-2018]

2] M. Chakraborty, S. Pal, R. Pramanik, and C. Ravindranath Chowdary, "Recent developments in social spam detection and combating techniques: A survey," Inf. Process. Manag., vol. 52, no. 6, pp. 1053-1073, Nov. 2016.

[3] A. Mehmood, B.-W. On, I. Lee, I. Ashraf, and G. Sang Choi, "Spam comments prediction using stacking with ensemble learning," J. Phys. Conf. Ser., vol. 933, p. 012012, Jan. 2018.

[4] H. Nguyen, "Research Report 2013 State of Social Media Spam," 2013.

[5] K. Stuart, "PewDiePie switches off YouTube comments: 'It's mainly spam," The Guardian, 2014. [Online]. Available: https://www.theguardian.com/technology/2014/sep/03/pewdie pie-switches-off-youtube-comments-its-mainly-spam. [Accessed: 02-Mar-2018].

[6] T. C. Alberto, J. V. Lochter, and T. A. Almeida, "TubeSpam: Comment Spam Filtering on YouTube," in 2015 IEEE 14th International Conference on Machine Learning and Applications (ICMLA), 2015, pp. 138-143.

[7] A. Pinandito, R. S. Perdana, M. C. Saputra, and H. M. Azzahra, "Spam detection framework for Android Twitter application using Naïve Bayes and K-Nearest Neighbor classifiers," in Proceedings of the 6th International Conference on Software and Computer Applications - ICSCA '17, 2017, pp. 77-82.

8] M. Alsaleh, A. Alarifi, F. Al-Quayed, and A. Al-Salman, "Combating Comment Spam with Machine Learning Approaches," in 2015 IEEE 14th International Conference on 
Imam Thoib, Arief Setyanto, Suwanto Raharjo Jurnal RESTI (Rekayasa Sistem dan Teknologi Informasi) Vol . 2 No. 3 (2018) 708 - 715

Machine Learning and Applications (ICMLA), 2015, pp. 295300.

[9] R. M. Silva, T. C. Alberto, T. A. Almeida, and A. Yamakami, "Towards filtering undesired short text messages using an online learning approach with semantic indexing," Expert Syst. Appl., vol. 83, pp. 314-325, Oct. 2017.

[10] T. A. Almeida, T. P. Silva, I. Santos, and J. M. Gómez Hidalgo, "Text normalization and semantic indexing to enhance Instant Messaging and SMS spam filtering," [16] Knowledge-Based Syst., vol. 108, pp. 25-32, Sep. 2016.

[11] I. Idris et al., "A combined negative selection algorithmparticle swarm optimization for an email spam detection [17] system," Eng. Appl. Artif. Intell., vol. 39, pp. 33-44, Mar. 2015.

[12] C.-N. Lee, Y.-R. Chen, and W.-G. Tzeng, "An online subjectbased spam filter using natural language features," in 2017 IEEE Conference on Dependable and Secure Computing, 2017, pp. 479-487.

[13] K. Roy, S. Keshari, and S. Giri, "Enhanced Bayesian spam filter technique employing LCS," in 2016 International Conference on Computer, Electrical \& Communication Engineering (ICCECE), 2016, pp. 1-6.

[14] M. Zavvar, M. Rezaei, and S. Garavand, "Email Spam
Detection Using Combination of Particle Swarm Optimization and Artificial Neural Network and Support Vector Machine," Int. J. Mod. Educ. Comput. Sci., vol. 8, no. 7, pp. 68-74, Jul. 2016.

[15] Q. Dang, F. Gao, and Y. Zhou, "Spammer detection based on Hidden Markov Model in micro-blogging," in 2016 12th World Congress on Intelligent Control and Automation (WCICA), 2016, pp. 407-412.

[16] S. Sedhai and A. Sun, "Semi-Supervised Spam Detection in Twitter Stream," IEEE Trans. Comput. Soc. Syst., pp. 1-7, 2017.

[17] T. Wu, S. Liu, J. Zhang, and Y. Xiang, "Twitter spam detection based on deep learning," in Proceedings of the Australasian Computer Science Week Multiconference on ACSW'17, 2017, pp. 1-8.

[18] S. Boughorbel, F. Jarray, and M. El-Anbari, "Optimal classifier for imbalanced data using Matthews Correlation Coefficient metric," PLoS One, vol. 12, no. 6, p. e0177678, Jun. 2017. 